\title{
Influence of water invasion on methane adsorption behavior in coal
}

Zhaofeng Wang ${ }^{1,2}$, Weiwei $\mathrm{Su}^{3}, \mathrm{Xu} \mathrm{Tang}^{4}$, Jiahao $\mathrm{Wu}^{5}$

(College of Safety Science and Engineering, Henan Polytechnic University, Jiaozuo, Henan, 454000, China; 2-MOE Engineering Center for Mine Disaster Prevention and Rescue, Jiaozuo, Henan, China; 3-CCTEG Shenyang research institute, Shenyang, 110016, China; 4 School of Chemistry, University of Nottingham, Nottingham, NG7 2RD UK; 5-School of Resources and Earth Science, China University of Mining and Technology, Xuzhou, Jiangsu 221116, China)

\section{Corresponding author: Xu Tang*}

E-mail: xutang2050@outlook.com

\section{Highlights:}

Experiments evidence that bulk water invasion displaces adsorbed methane in coal. The displace efficiency depends on equilibrium pressure and invasion water content. The displacement effects can be attributed to capillary effects and preferential flow. This work provides insights for coal seam gas drainage design using water invasion.

\begin{abstract}
:
Fluid displacement is the fundamental process for subsurface fossil fuels extraction. Water invasion in coal seams is one of the routinely used stimulation approaches for coal seam methane extraction in underground coal mines. However, how the invading bulk water interacts with adsorbed/gaseous methane in coal is rarely considered even though it is known that moisture presence in coal decreases methane uptake by occupying adsorption sites. Here we study how the invading water interacts with adsorbed/gaseous methane in molded coal under elevated pressures using a custom-designed instrument; the test procedure mimics the real water invasion process in engineering applications. Experimental results demonstrate that invasion water displaces adsorbed methane in nanopores of coal and thus enhances the free gas content. The displacement mechanism can be attributed to capillary effect and preferential flow in a coating mode. It was found that Philip's sorptivity model can simulate the relationship between displaced methane content and time, and the obtained sorptivity increases with increasing water invasion content and is independent of gas pressure. It was observed that the higher the initial adsorption equilibrium pressure, the larger the displaced methane content, and this can be attributed to the pressure-dependent feature of adsorbed methane density. The higher the invasion water content, the higher the displaced methane content. These experimental results are also applied for optimizing gas drainage borehole arrangement to efficiently drain coal seam gas in underground coal mines. These findings provide a new perspective to understand the interactions between bulk water and methane in coals and pave the way for developing new technologies for methane recovery in coal seams.
\end{abstract}

Key words: coal, water, methane, imbibition, adsorption, displacement

This work has been accepted by International Journal of Coal Geology. 


\section{Introduction}

Fluid-fluid displacement in coal is important for coal bed methane (CBM) extraction by fluids injection stimulation techniques such as gas, water and heat injection (Rogers et al., 2007; White et al., 2005; Seidle et al., 2011; Salmachi et al., 2012). CBM in subsurface coal seams exists mainly in adsorbed phase (adsorbed methane) and bulk gas phase (free methane) with a small fraction of dissolved methane in formation water, and the adsorbed methane typically dominants and accounts for $80-90 \%$ of the total gas in place content. Since water production always accompanies the economic production of CBM, it is important to study water and methane interactions in coals (Rogers et al., 2007; Seidle et al., 2011; Ibrahim et al., 2015). Geological carbon dioxide sequestrations in coal seams demonstrate that gaseous carbon dioxide injection could displace adsorbed methane and thus enhance CBM recovery because of the higher affinity of carbon dioxide over methane (Gale et al., 2001; Godec et al., 2014; White et al., 2005; Busch, et al., 2011). The water injection technologies are also applied in the mining industry for coal and outburst prevention as well as coal dust control (Colinet et al., 2010; Xiao, et al., 2009; Lin et al, 2018; Huang et al., 2011). However, for bulk water and methane interaction in coal, the system becomes a complex four-phase system including free methane, adsorbed methane, liquid water and porous coal. How the bulk water interacts with the adsorbed methane still remains unclear. Therefore, in-depth study of water-coal-gas interaction has an urgent need to optimize water invasion technology and to enhance CBM extraction efficiency.

Since all virgin coals in the subsurface contain moisture, studying how moisture influences methane adsorption capacity of coal always arises researcher's interests. In 1936, it was observed that the methane sorption capacity decreases because of the moisture in several Belgian coals (Coppens, 1936). In 1973, both dry and moisture equilibrated coals are used to study moisture influence on the adsorption capacity of American coals, and the results indicate that only the adsorbed moisture affects the methane adsorption capacity of coal and water present in excess of the adsorbed water has no effect on methane sorption (Joubert et al., 1973, 1974). The similar test methods are adopted to study moisture influence on gases adsorption capacity of coals from different coal basins in the world (Hall et al.; 1994; Levy et al., 1997; Lynch et al., 1982; Allardice et al., 2003; Busch et al., 2007; Clarkson and Bustin, 2000; Day et al., 2008; Fei et al., 2006; Fitzgerald et al., 2005; Krooss et al., 2002; Suuberg et al., 1993; Lynch and Webster, 1982; Unsworth et al., 1989; Wang et al., 2014; Guo et al., 2015). Beside the validation with Jourbert's conclusion, these studies show that high rank coals were less affected by the presence of moisture than low rank coals, methane sorption capacity is less sensitive to changes in temperature than to variation in moistures, the reduction of methane sorption capacity due to moisture can be related with the oxygen content of coal, and pre-adsorbed water only has a minor influence on the thermodynamic properties of methane sorption in coal. Molecular simulation studies also reveal that the presence of water in the coal matrix reduces the interaction between the coal and methane and thus decreases the adsorption capacity and the adsorption rates (Zhang et al., 2014). In order to further understand how moisture exists in moisture equilibrated coal, water vapor sorption tests in coal and other carbonaceous materials are conducted (Mahajan and Walker, 1970; Darcey et al., 1958; McCutcheon et al., 2001 \& 2003; Moore et al., 2006; Charrière et al., 2010; Švábová et al., 2011; Wiig et al., 1949; Nishino, 2001; Yu et al., 
2013; Wan et al., 2016; Seemann et al., 2017). It was found that water vapor's existing status in coal depends on the surface chemistry and pore structure as well as the environments (vapor pressure and temperature). As the pressure of the water vapor increases, the vapor sorbs on the primary sites first followed by sorption on secondary sites via hydrogen bonding and finally forms water clusters as well as capillary water when pressure is high enough (Given et al., 1986; Gutierrez-Rodriguez et al., 1984; Lynch and Webster, 1982; Nishino, 2001; Brennan et al., 2001; liyama et al., 1997; Yu et al., 2013). Water clusters have been observed using in-situ small-angle neutron scattering approach (Bahadur et al.,2017). The hysteresis behavior of ad- and de-sorption water vapor isotherm is attributed the effect of the pore surface chemistry (wetting properties and surface functional groups) as well as the pore structure of coal, and the hysteresis loop is also found to be temperature-dependent (Brenan et al., 2001; Tang et al., 2017; Allardice et al., 1971; Mahajan and Walker, 1970; McCutcheon et al., 2001 and Charrière et al., 2010; Seemann et al., 2017). The water vapor uptake is higher for high rank coals compared to low rank coal which is attributed to the rank-dependent micropore volume and surface chemistry properties. The surface chemistry control is validated by a recent study showing that water sorption in mudrocks seems to be controlled by surface chemistry rather than pore size (Seemann et al., 2017). For thermodynamic analysis, the isosteric enthalpy (heat) of adsorption for water vapor adsorption is found to be both water uptake dependent and temperature dependent (Tang et al., 2017). The hydrogen bonding for water molecules could produce higher heat of adsorption (Mahajan and Walker, 1970; Darcey et al., 1958). These aforementioned studies are very important to understand in which form pre-adsorbed water exists and interacts with dosed methane at an equilibrium status. However, some hypothesis from these studies still need to be validated by experiments such as the concept of "volumetric displacement of gases" (Day et al., 2008; Busch et al., 2011). These studies claim that the loss of the capacity of moisture equilibrated coals can be simply interpreted by the adsorbed water volumetrically occupying the adsorption sites for gases such as methane and carbon dioxide. Therefore, experimental studies on water and methane interaction in coal are needed to verify the hypothesis and advance the understanding of the displacement mechanism.

Water invasion is historically used in underground coal mines for mining safety as well as occupational health because injected water increases the permeability of coal seams by fracturing coal seams and decrease dust during coal cutting and transportation (Colinet et al., 2010; Xiao, et al., 2009). Several water-invasion based techniques are proposed and applied in underground coal mines for coal and gas outburst prevention such as hydraulic slot, hydraulic cutting, hydraulic fracturing and high pressure pulsed water (Lin et al, 2018; Huang et al., 2011; Guo et al., 2010). Laboratory tests were also conducted to understand methane transport behavior in coal with water invasion. It was found that pre-adsorbed water in the coal matrix significantly decreases the methane ad-/de-sorption rate and inhibits gas transport (Pan et al., 2010; Wang et al., 2014; Švábová et al., 2012), which was also observed in coalbed methane industry that water could damage the coal seam reservoirs (Bennion et al., 1996 \& 1999). The numerical simulation study also indicates that moisture loss in coal seams can significantly improve coal permeability and thus enhance gas production for coalbed methane wells (Chen et al., 2012; Teng et al., 2016; Pan et al., 2010). The impact of invasion water on methane desorption in coal was studied by a custom-made instrument, and it was found that injected water decreases the 
diffusion coefficient of methane in coal and finally inhibits methane transport (Chen et al., 2015). The outburst prediction index, coal cutting desorption index, decreases with increasing moisture content, and high moisture content decreases the accumulated desorption methane content (Jiang et al., 2015). Some water imbibition tests in coal were conducted but the displacement mechanism is not analyzed as well as the potential implication for underground coal mine methane drainage using water invasion based techniques (Wang et al., 2015; Wang et al., 2016; Wu et al., 2018). A recent experimental study revealed the role of water in methane adsorption and diffusion in nanoporous silica of $0.5,3$ and $6 \mathrm{~nm}$ by hyperpolarized $129 \mathrm{Xe}$ and $1 \mathrm{H}$ PFG NMR spectroscopy (Hu et al., 2018). The results showed that the introduction of water vapor in a methane-silica nanopore sorption system breaks the initial equilibrium status and inhibits the adsorption of methane, but the inhibiting effect is weakened in larger pores. It was also found that the methane diffusion depends on the adsorption state of water because the adsorbed water can either form a thin layer or water clusters in pores; both of which affect the apparent pore size and methane transport behavior differently (Hu et al., 2018). Overall, the aforementioned studies provide a solid foundation for understanding preadsorbed water and water vapor injection influence on methane transport in coals. However, the influence of injected bulk water on methane transport in coal is still unclear. For example, how the bulk water interacts with adsorbed methane has not been validated even though a numerical study shows that the adsorption capacity of water in coal is higher than methane and carbon dioxide (Zhou et al, 2016; Jin et al., 2016; Liu et al., 2016). Therefore, experimental studies on the interaction between injected bulk water and methane interaction in coals is an urgent need.

In this work, the interaction between invasion bulk water and methane in molded coals is studied by using a house-made instrument. How the environmental factors such as invasion water content and methane equilibrium pressure affect the interaction between injected water and methane in coals are investigated. Both the kinetics process and equilibrium status are also analyzed based on the experimental results. The potential engineering applications of the results are also discussed, which provides the foundation to optimize borehole arrangement plans for coal seam methane drainage.

\section{Materials and methodology}

\subsection{Physical properties of coal}

Anthracite samples came from the Yonghong coal mine, Jincheng, located in the Shanxi province of China are used in this work. The physical parameters of coal were evaluated using Chinese national standards (Table 1): ash content $\left(A_{a d}\right)$, volatile matter $\left(V_{a d}\right)$, moisture (Mad), true relative density (TRD), apparent relative density (ARD), and porosity.

\section{Table 1 Physical parameters of coal}

\begin{tabular}{ccccccc}
\hline $\begin{array}{c}\text { Physical } \\
\text { parameters }\end{array}$ & $\begin{array}{c}\mathrm{M}_{\mathrm{ad}} \\
(\%)\end{array}$ & $\begin{array}{c}\mathrm{A}_{\mathrm{ad}} \\
(\%)\end{array}$ & $\begin{array}{c}\mathrm{V}_{\mathrm{ad}} \\
(\%)\end{array}$ & $\begin{array}{c}\mathrm{TRD} \\
\left(\mathrm{g} / \mathrm{cm}^{3}\right)\end{array}$ & $\begin{array}{c}\text { ARD } \\
\left(\mathrm{g} / \mathrm{cm}^{3}\right)\end{array}$ & $\begin{array}{c}\text { Porosity } \\
(\%)\end{array}$ \\
\hline Value & 1.80 & 8.07 & 5.91 & 1.51 & 1.35 & 10.60 \\
\hline
\end{tabular}


The pore size distribution of the samples is characterized by mercury intrusion porosimetry (MIP) using the AUTOPORE E950 (Micromeritics, Norcross, GA, USA). The pore distribution could be obtained by the Washburn equation,

$r=\frac{2 \sigma \cos \theta}{p_{c}}$

Where $r$ is the pore throat of pores, $\sigma$ is the surface tension of mercury, $\theta$ is the contact angle between mercury and coal surface, $p_{c}$ is the external pressure. Pore size distribution of coal is shown in Table 2.

Table 2 Pore size distribution of coal using MIP

\begin{tabular}{|c|c|c|c|}
\hline Sample name & Pore size $(\mathbf{n m})$ & Pore volume $\left(\mathrm{cm}^{\mathbf{3}} / \mathbf{g}\right)$ & Specific Surface area $\left(\mathbf{m}^{\mathbf{2}} / \mathbf{g}\right)$ \\
\hline \multirow{3}{*}{$\begin{array}{c}\text { Yonghong No. 3 } \\
\text { coal sample }\end{array}$} & $>1000$ & 0.0027 & 0.01 \\
\cline { 2 - 4 } & $100-1000$ & 0.0042 & 0.064 \\
\cline { 2 - 4 } & $10-100$ & 0.0104 & 1.993 \\
\cline { 2 - 4 } & $<10 \mathrm{~nm}$ & 0.0095 & 5.223 \\
\hline
\end{tabular}

\subsection{Sample preparation}

The coal samples were ground and sieved using different sizes of metal sifters and placed in a drying oven at $105^{\circ} \mathrm{C}$ for $24 \mathrm{~h}$ to dehydrate. After dehydration, the prepared samples were stored in a desiccator for later use. The coal and water mixture was first prepared by mixing three different sizes of coal particles $((0.25-0.5) \mathrm{mm}:(0.2-0.25) \mathrm{mm}:(<0.2) \mathrm{mm}$ $=2: 2: 1)$ with distilled water. The prepared coal and water mixtures were compacted using a material testing system (MTS) machine by applying $200 \mathrm{kN}$ loading, which finally produces a cylindrical molded coal $(\varphi 50 \times 80 \mathrm{~mm})$. The height determination of the molded coal is referred to Supplemental Materials. The prepared molded coals are then dried at $105{ }^{\circ} \mathrm{C}$ and then kept in a desiccator for later use.

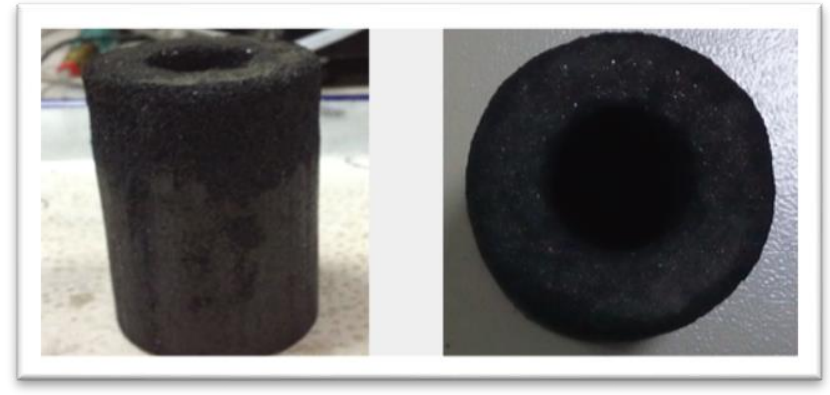

Figure 1 Molded coal with part hollow center for water invasion test; the hollow center is designed to hold the water container for the imbibition tests.

It is worth noting that the molded coal is used in this work instead of coal core for several reasons. First, the custom-designed methane pressurized instrument requires the specific shape of the coal sample, and it is challenging to prepare coal sample from coal core. Second, using crushed sample to measure methane adsorption uptake is routinely used to estimate the methane adsorption capacity in coals in both industry and academia. Third, the main challenge of using intact core coal for adsorption isotherms measurement 
is the unpractical long waiting time to reach equilibrium status. Therefore, this work uses molded coal in this work, which is practical and efficient to reach the research goal.

\subsection{Experimental procedure}

The water and methane interaction tests are conducted following steps below:

1. The tightness of the whole system is double-checked to ensure both pipelines and connections are tight enough for the test. The leakage rate of the testing system is $4.68 \times 10^{-4} \mathrm{MPa} / \mathrm{h}$ and is acceptable (Zhang et al., 2012). Thermostatic water bath is set at $30 \pm 1^{\circ} \mathrm{C}$.

2. The prepared molded coal and water container ( $\left.V_{\text {container }}\right)$ fully filled with a distilled liquid water $\left(\mathrm{V}_{\mathrm{H} 2 \mathrm{O}}\right)$ are placed inside the test cell. The molded coals are prepared to perfectly fit the water container. Then, the whole system is vacuumed until it stabilizes at $20 \mathrm{~Pa}$.

3. Helium (99.99\%) is dosed into the test cell through the reference cell to determine the free space $\left(\mathrm{V}_{\mathrm{He}}\right)$ of the test cell (excluded the skeleton volume of coal and water container). After the free space is measured, the system is vacuumed again until it stabilizes at $20 \mathrm{~Pa}$.

4. A certain amount of methane $99.99 \%$ (Min) is dosed into the sample cell (usually multiple times) until the coal and methane system reaches adsorption equilibrium at a predefined pressure. This is indicated by the constant reading of the pressure transducer. The equilibrium process typically takes around 10 to 15 hours for the powder samples and the equilibrium time also depends on the material property of the sample.

5. The needle valve is screwed to connect the water container and molded coal, and the whole test cell is inversed $180^{\circ}$ simultaneously. This step allows water, stored in the container, to flow into the molded coal completely. The process therefore initiates water and methane interaction test, and the pressure transducer of the test cell continuously records during the test.

6. Once the system reaches a new equilibrium (when the reading of the pressure transducer of the test cell does not change), the test is terminated and methane is vented out.

The schematic illustration of the custom-made instrument is shown in Figure 2. It is worth noting that the dissolved methane in water as well as the swelling of coal due to water absorption are neglected in this work because the solubility of methane in water is 22.7 $\mathrm{mg} / \mathrm{L}$ and the coal welling volume is less than $1.5 \%$ of the total coal volume (Liu et al., 2016; Van Bergen et al., 2009; Pan et al., 2010). 


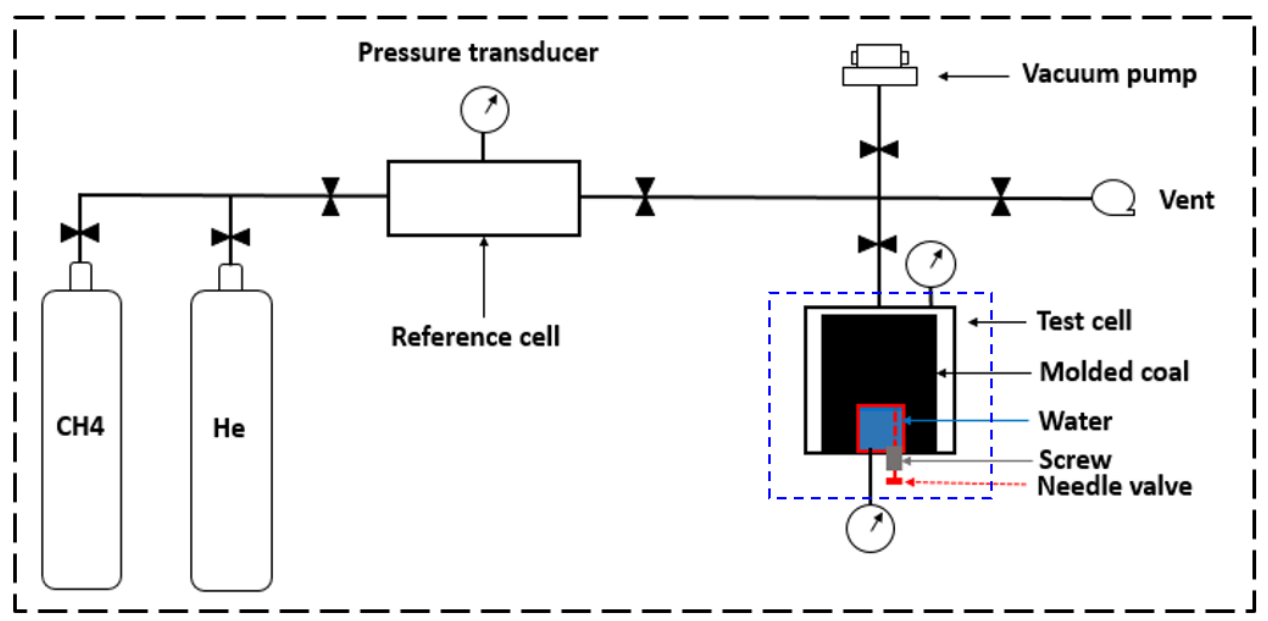

Figure 2 Schematic illustration for methane and water interaction in molded coal under elevated pressurizes. The blue dotted rectangular represents thermostatic water bath.

\subsection{Data acquisition principle}

According to the test procedure and experimental setup in Section 2.3, the data acquisition principle is detailed in this section. When a certain amount of methane $\left(\mathrm{Min}_{\mathrm{in}}\right)$ is dosed into the test cell from the reference cell and the coal-methane sorption system reaches equilibrium, the adsorption uptake $\left(n_{a}^{\prime}\right)$ can be calculated by the mass balance of system (equation (1)) (Rouquerol et al., 2013),

$n_{a}^{\prime}=M_{\text {in }}-n_{\text {free }}^{\prime}=M_{\text {in }}-V_{H e} \cdot \rho_{C H_{4}}^{\prime}$

Where $\mathrm{Min}$ is the dosed amount of methane, $n_{\text {free }}^{\prime}$ is free methane in the test cell at equilibrium status, $\mathrm{V}_{\mathrm{He}}$ is the free volume of test cell measured by Helium, and $\rho_{\mathrm{CH}_{4}}^{\prime}$ is the density of free methane. $\rho_{\mathrm{CH}_{4}}^{\prime}$ is a function of pressure and temperature and thus can be obtained by the reading of the pressure transducer and temperature gage of the water bath.

When water from the container flows into the molded coal, the initial methane-coal sorption system will be disturbed. Thus, the new methane- coal-water interaction system reaches another new equilibrium, the adsorption uptake of the new equilibrium $\left(n_{a}^{\prime \prime}\right)$ can be calculated by the mass balance of system (equation (2)),

$$
M_{\text {in }}+m_{H_{2} \mathrm{O}}=n_{a}^{\prime \prime}-\left(V_{\mathrm{He}}+V_{\text {container }}-V_{\mathrm{H}_{2} \mathrm{O}}\right) \cdot \rho_{\mathrm{CH}_{4}}^{\prime \prime}+m_{\mathrm{H}_{2} \mathrm{O}}
$$

Where $\mathrm{mH}_{20}$ is the mass of the water, $\mathrm{V}_{\text {container }}$ is the volume of the container, $\mathrm{V}_{\text {H2O }}$ is the volume of the invading water. Since the container is full of water, i.e., $\mathrm{V}_{\text {container }}=\mathrm{V}_{\mathrm{H} 2 \mathrm{O}}$, equation (2) can be simplified to equation (3),

$n_{a}^{\prime \prime}=M_{\text {in }}-n_{\text {free }}^{\prime \prime}=M_{i n}-V_{H e} \cdot \rho_{C_{4}}^{\prime \prime}$ 
If there is no interaction between invading water and methane in coal, there should be no difference between equation (1) and (3), i.e. the pressure of the test cell will not change. This means the same volume of invading water displace the same volume of bulk gas, and invading water does not interact with adsorbed methane. However, if there is interaction between water and adsorbed methane, the initial equilibrium of the sorption system will be interrupted. The pressure of the test chamber will change because the invading water will displace adsorbed methane by transforming dense adsorbed methane into gaseous methane. The water-methane-coal system will reach a new equilibrium status when the pressure of test cell does not change. It is worth noting that the adsorption uptakes $\left(n_{a}^{\prime}, n_{a}^{\prime \prime}\right)$ are Gibbs excess adsorption uptakes and can be treated as the true (absolute) adsorption uptake under low pressure conditions (<15 MPa) according Gibbs excess adsorption theory (Tang et al., 2017).

\subsection{Equilibrium status determination for the methane and molded coal system}

It is critical to make sure that the methane-dry coal adsorption system reaches equilibrium prior to initiating the water invasion process. Since there is no standard for determining equilibrium status for the gas and coal sorption system, a pressure monitoring test is conducted to determine the equilibrium status of the molded coal and methane adsorption system (Tang et al., 2015; Wang et al., 2015). Figure 3 shows how the pressure of the sample cell changes with time. The initial pressure of the sample cell is $4.7 \mathrm{MPa}$, and the final equilibrium pressure is $0.94 \mathrm{MPa}$. In the first two hours, there is a sharp decrease of the pressure. After 6.24 hours, the pressure of the cell remains almost constant at 0.96 $\mathrm{MPa}$. The pressure at 4.3 hours and 29.95 hours is $0.972 \mathrm{MPa}$ and $0.96 \mathrm{MPa}$, respectively. Therefore, the equilibrium time for molded coal and methane system is set to 12 hours to ensure the system reaches equilibrium status prior to initiating the water imbibition tests.

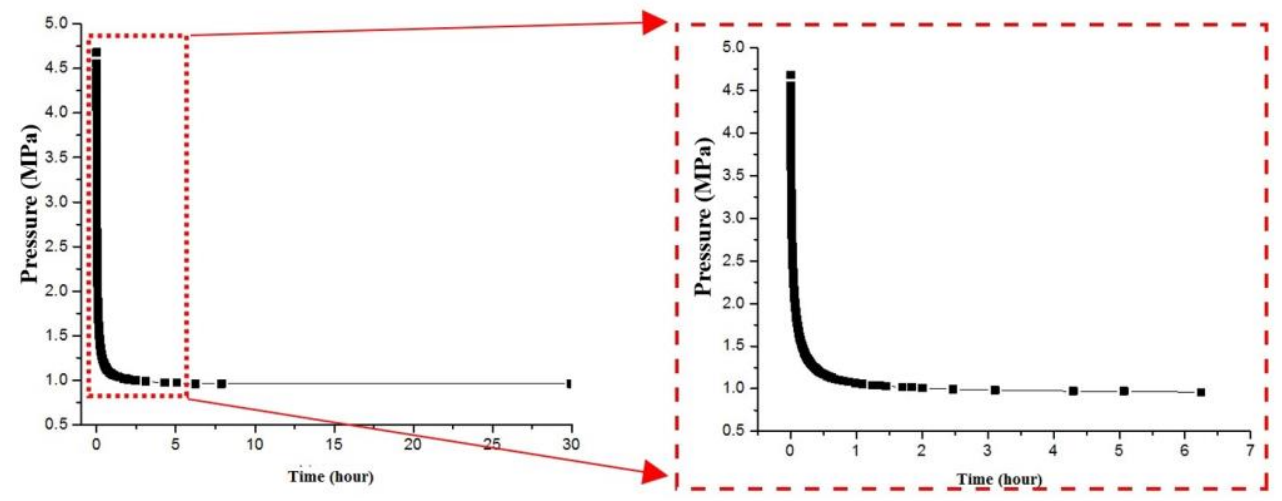

Figure 3 Pressure change of the methane and molded coal cell with time at $30^{\circ} \mathrm{C}$

\section{Experimental results and discussion}

Eighteen water invasion tests were conducted in this work and these experiments allow us to investigate how the initial equilibrium pressures $(0.5,0.74,1.0,1.5,2 \mathrm{MPa})$ and invasion water content $(2 \%, 4 \%, 6 \%, 8 \%, 10 \%)$ influences the interaction between invasion water and methane in dry molded coal. The invasion water content is the mass ratio between invasion water and molded coal, that is, invasion water content is normalized to the dry mass of the coal. The preliminary experiments indicate that the 
molded coal have the capacity to imbibe around $18 \%$ water content completely, and details are referred to the Supplemental Materials.

\subsection{Observation of gas pressure variation in test chamber}

The pressure of the sample cell increases with time due to water absorption in molded coals at different pressure and water invasion content conditions. Under the same initial equilibrium pressure conditions (1.5 MPa and 2.5 MPa), the trend is clear that the higher the water absorption uptake, the larger the final equilibrium pressure. Under the same water invasion content conditions (4\% and $10 \%)$, the higher the initial pressure of the testing chamber, the larger the final equilibrium pressures. The experimental results are shown in Figure 4. It is worth noting that even though the molded coals are prepared under the same conditions, the mass of molded coal is different because of the heterogeneous characteristics of crushed coal particles. This results in the difference of the free space in the sample cells, and the difference leads to a higher pressure increase of molded coal at $8 \%$ and $6 \%$ water absorption uptake under $1.5 \mathrm{MPa}$ compared to the results under 2.5 MPa. This is because the pressure is an absolute index for the adsorption system and does not account for the mass difference of the modelled coal samples. When the displaced methane is unified by coal of unit mass, the abnormal phenomena disappear as shown in the following Section 3.2.
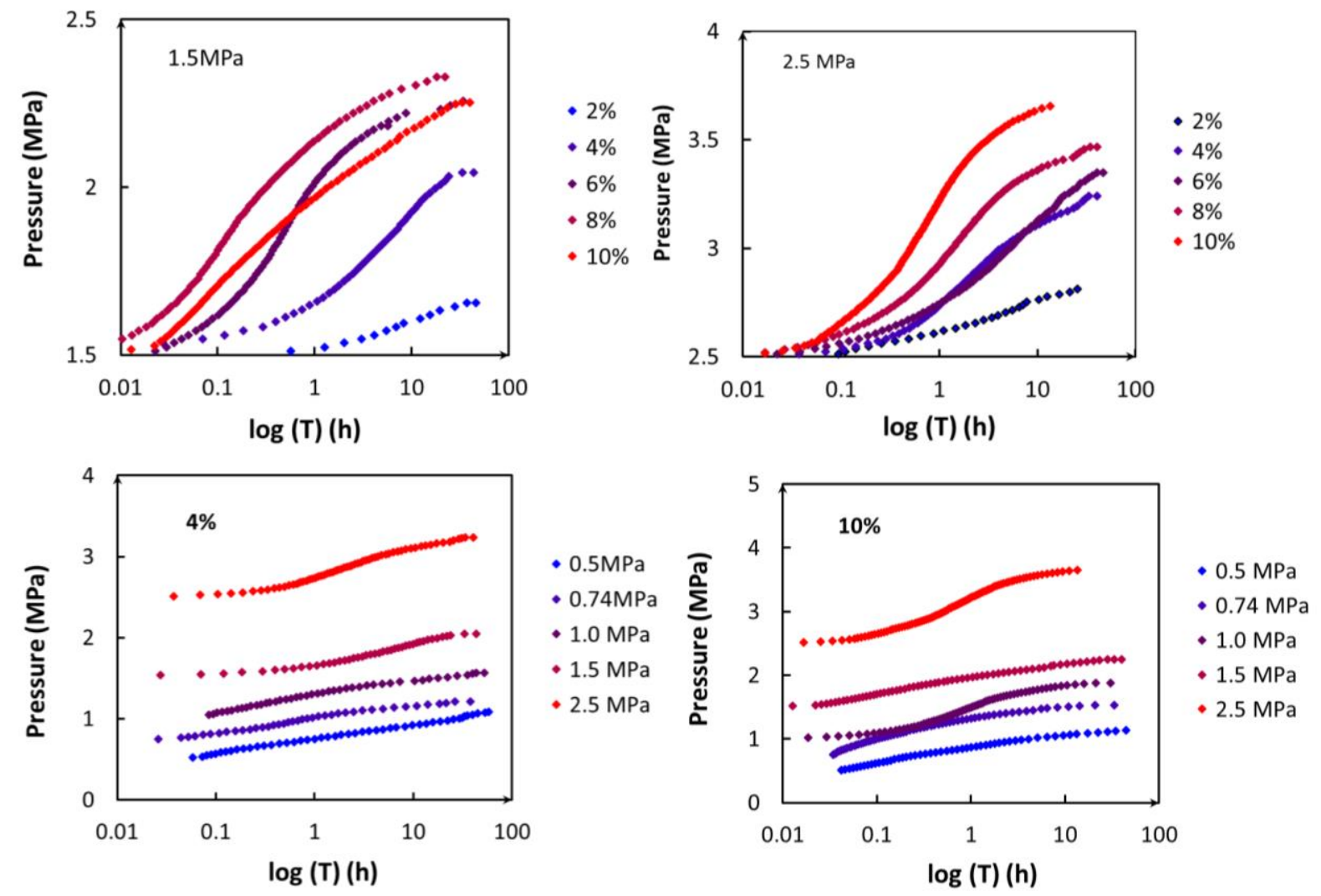

Figure 4 Pressure change of sample cell with time at different pressure and water invasion content conditions

Pressure increase of the test cell directly evidences that water absorption displaces condensed adsorbed methane in coal and enhances the bulk gas content in the sorption 
system according to the measuring principle in Section 2.4. This observed phenomenon also agrees with previous experimental and simulation studies that the initial moisture in coal significantly decreases the adsorption capacity of methane in coal by occupying available adsorption sites prior to methane adsorption (Joubert et al., 1974 \& 1973; Zhang et al., 2014; Day et al., 2008; Hu et al, 2018). It is worth noting that even though the effect is similar, the mechanism for these observations are different because the fluid dosing sequence in our test is different from that in previous studies. Our tests dose bulk water in the methane-coal equilibrium system while previous studies dose methane in the moisture-coal equilibrium system. Figure 4 also indicates that the pressure increase of the testing chamber depends on both initial equilibrium pressure and the water invasion content. Since coal may swell in the presence of water, the volume expansion of coal may also contribute to the increased pressure of the testing cell which cannot be excluded in this work. However, the contribution of coal swelling for the increased pressure can be ignored here because the coal welling is less than $1.5 \%$ of the total volume (Liu et al., 2016; Van Bergen et al., 2009; Pan et al., 2010).

\subsection{Quantification of gaseous and adsorbed methane behavior}

In Section 3, it has been observed that the pressure of the coal and methane adsorption system increases because of the invasion of bulk water in molded coals. By recording the reading of the pressure in the testing chamber and applying equations (1-3), the gaseous and adsorbed methane quantity is obtained. This section will discuss how the initial equilibrium pressure and invasion water content influence the adsorbed and gaseous methane in the test cell.

It is well known that sorptivity has the capacity to quantify the rate of water imbibition in porous media, which is controlled by both the capillary pressure and permeability of the porous media (Philip, 1957; Humphrey et al., 1996; Hu et al, 2001). The sorptivity is a very useful index for characterizing water transient imbibition process. Considering a semi-infinite, homogenous, one dimensional medium where water is imbibed at one end, Philip proposed that the cumulative of water is a function of time as (Philip, 1957):

$$
I(t)=S t^{0.5}+A t
$$

Where $\mathrm{I}(\mathrm{t})$ is cumulative imbibition water content, $\mathrm{t}$ is time, $\mathrm{S}$ is the sorptivity, $\mathrm{A}$ is an empirical constant depending on medium properties and environments. The term $S t^{0.5}$ dominates equation (4) in early times when gravity potential gradient are small relative to matric potential gradients (Philip, 1957). Under this condition, the slope of $I(t)$ versus $t^{0.5}$ is the sorptivity. Considering the fact that the methane enrichment is only caused by the water imbibition in molded coals in this work, the authors adopt equation (4) to quantify the relationship between displaced methane content and time. This allows the authors to investigate how the initial equilibrium pressure and invasion water content influences the sorptivity of molded coals. Philip's model accurately mimics the relationship between displaced methane content and time in earlier time of the test, as shown in Figure 5 and Table 3. 

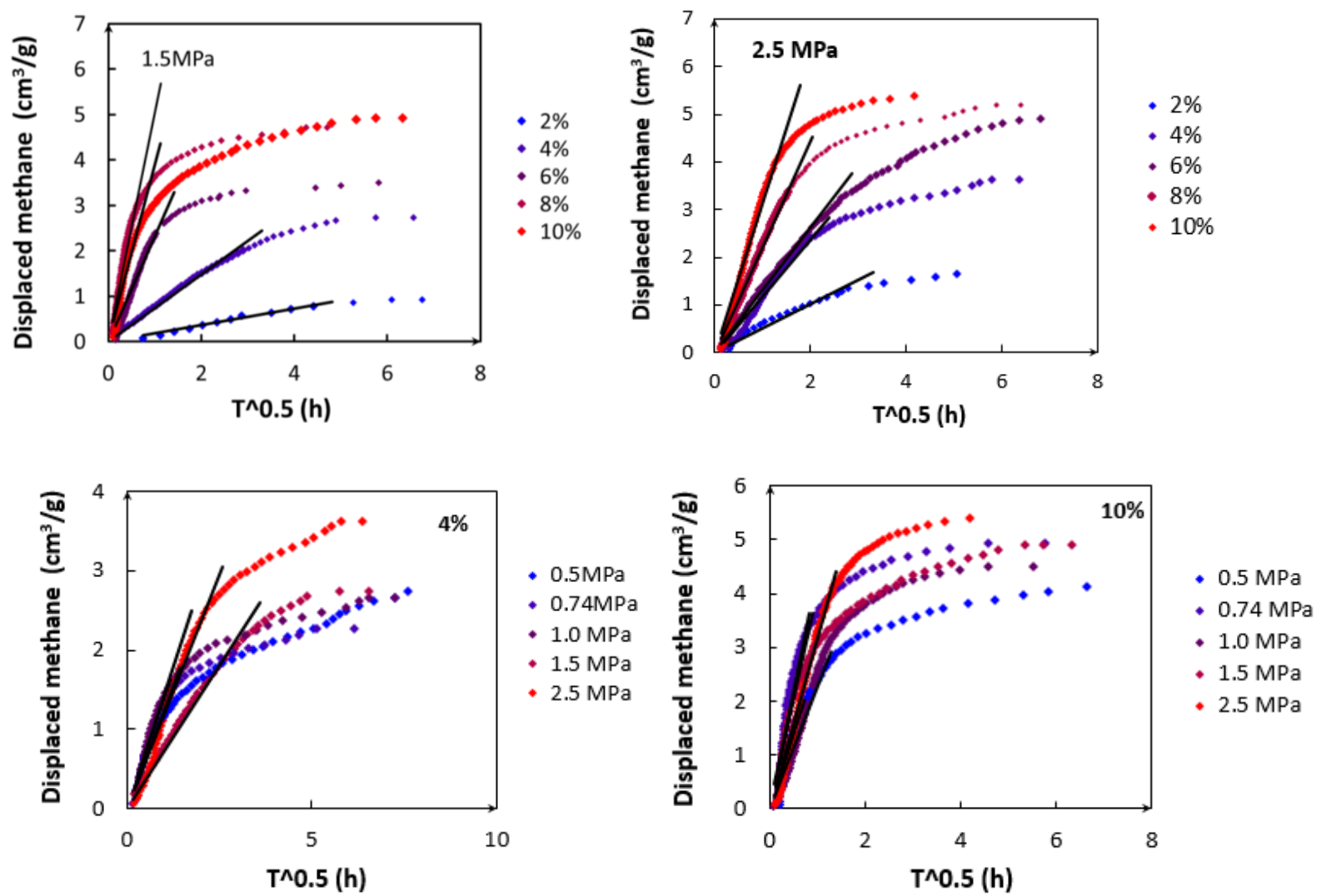

Figure 5 Displaced methane content at different initial equilibrium pressure and water invasion contents: solid lines represent fitting lines using the relation, $I(t)=S t^{0.5}$.

\section{Table 3 Fitting equations for sorptivity}

\begin{tabular}{|c|c|c|c|c|c|c|c|}
\hline \multicolumn{2}{|c|}{ Test condition } & \multirow{2}{*}{\begin{tabular}{|c|} 
Fitting equation \\
$\mathrm{I}(\mathrm{t})=0.5064 * \mathrm{t}^{\wedge} 0.5$ \\
\end{tabular}} & \multirow{2}{*}{$\begin{array}{c}\mathbf{R}^{\mathbf{2}} \\
0.9683 \\
\end{array}$} & \multicolumn{2}{|c|}{ Test condition } & \multirow{2}{*}{$\begin{array}{c}\text { Fitting equation } \\
\mathrm{I}(\mathrm{t})=2.7466 * \mathrm{t}^{\wedge} 0.5\end{array}$} & \multirow{2}{*}{$\frac{\mathbf{R}^{2}}{0.8756}$} \\
\hline \multirow{5}{*}{$2.5 \mathrm{MPa}$} & $2 \%$ & & & \multirow{5}{*}{$10 \%$} & $0.5 \mathrm{MPa}$ & & \\
\hline & $4 \%$ & $\mathrm{I}(\mathrm{t})=0.184 * \mathrm{t}^{\wedge} 0.5$ & 0.9592 & & $0.74 \mathrm{MPa}$ & $\mathrm{I}(\mathrm{t})=4.2949 * \mathrm{t}^{\wedge} 0.5$ & 0.6504 \\
\hline & $6 \%$ & $\mathrm{I}(\mathrm{t})=1.3046 * \mathrm{t}^{\wedge} 0.5$ & 0.9930 & & $1.0 \mathrm{MPa}$ & $\mathrm{I}(\mathrm{t})=2.2601 * \mathrm{t}^{\wedge} 0.5$ & 0.9402 \\
\hline & $8 \%$ & $\mathrm{I}(\mathrm{t})=2.2301 * \mathrm{t}^{\wedge} 0.5$ & 0.9914 & & $1.5 \mathrm{MPa}$ & $\mathrm{I}(\mathrm{t})=3.988 * \mathrm{t}^{\wedge} 0.5$ & 0.9269 \\
\hline & $10 \%$ & $\mathrm{I}(\mathrm{t})=3.1568 * \mathrm{t}^{\wedge} 0.5$ & 0.9710 & & $2.5 \mathrm{MPa}$ & $\mathrm{I}(\mathrm{t})=3.1453 * \mathrm{t}^{\wedge} 0.5$ & 0.9610 \\
\hline \multirow{5}{*}{$1.5 \mathrm{MPa}$} & $2 \%$ & $\mathrm{I}(\mathrm{t})=0.1811^{*} \mathrm{t}^{\wedge} 0.5$ & 0.9742 & \multirow{5}{*}{$4 \%$} & $0.5 \mathrm{MPa}$ & $\mathrm{I}(\mathrm{t})=1.2585^{*} \mathrm{t}^{\wedge} 0.5$ & 0.9230 \\
\hline & $4 \%$ & $\mathrm{I}(\mathrm{t})=0.7395 * \mathrm{t}^{\wedge} 0.5$ & 0.9896 & & $0.74 \mathrm{MPa}$ & $\mathrm{I}(\mathrm{t})=1.3264 * \mathrm{t}^{\wedge} 0.5$ & 0.9722 \\
\hline & $6 \%$ & $\mathrm{I}(\mathrm{t})=2.3243 * \mathrm{t}^{\wedge} 0.5$ & 0.9566 & & $1.0 \mathrm{MPa}$ & $\mathrm{I}(\mathrm{t})=1.4303 * \mathrm{t}^{\wedge} 0.5$ & 0.9522 \\
\hline & $8 \%$ & $\mathrm{I}(\mathrm{t})=5.0686 * \mathrm{t}^{\wedge} 0.5$ & 0.9594 & & $1.5 \mathrm{MPa}$ & $\mathrm{I}(\mathrm{t})=0.7233 * \mathrm{t}^{\wedge} 0.5$ & 0.9848 \\
\hline & $10 \%$ & $I(t)=3.9164 * t^{\wedge} 0.5$ & 0.9410 & & $2.5 \mathrm{MPa}$ & $\mathrm{I}(\mathrm{t})=1.1789 * \mathrm{t}^{\wedge} 0.5$ & 0.9708 \\
\hline
\end{tabular}

Based on the successful application of the model, the results of calculated sorptivity under different test conditions are obtained. It is observed that the higher the water invasion content, the higher the calculated sorptivity, and there are no consistent relationships between initial equilibrium pressure and sorptivity, as shown in Figure 6. The reason is the sorptivity is essentially a measure of the medium capacity to absorb/desorb liquids by capillarity and is independent of gas pressure under low pressure conditions (below 
2.5MPa in this work) (Philip, 1957; Hu et al, 2001). The large amount of water invasion content actually accelerates the water transport in coal and thus increases the sorptivity.
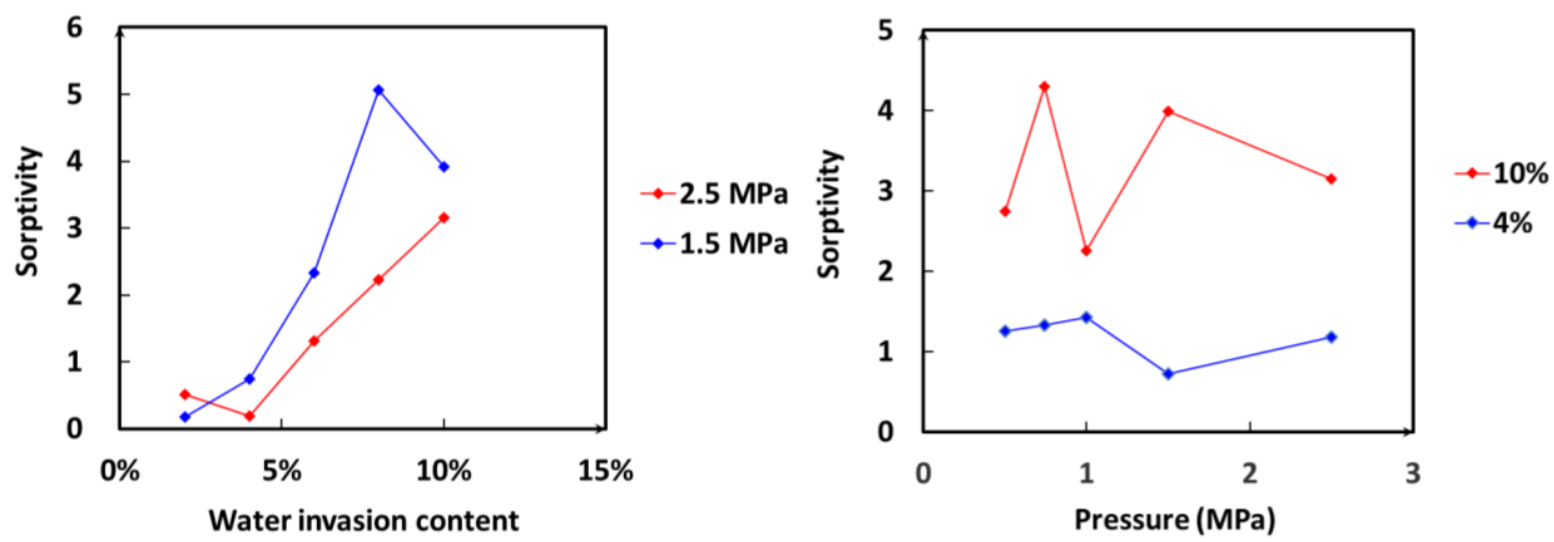

Figure 6 Relationship between sorptivity and water invasion content and initial equilibrium pressure

At the end of each test, when the new equilibrium status for the invasion water-methanecoal system is reached, the relationship between methane quantity and water invasion content and initial equilibrium pressure are also obtained. Under the same equilibrium pressure conditions (1.5 and $2.5 \mathrm{MPa}$ ), the displaced methane content increases with increasing water invasion content and the adsorbed methane content decreases simultaneously. The higher the equilibrium pressures, the higher the displaced methane quantity. Under same invasion water conditions (4\% and 10\%), both the displaced methane and residual adsorbed methane increase with increasing pressures. The higher the invasion water content, the higher the displaced methane quantity. All observations agree with each other as shown in Figure $7 \mathrm{a}$ and $7 \mathrm{~b}$.
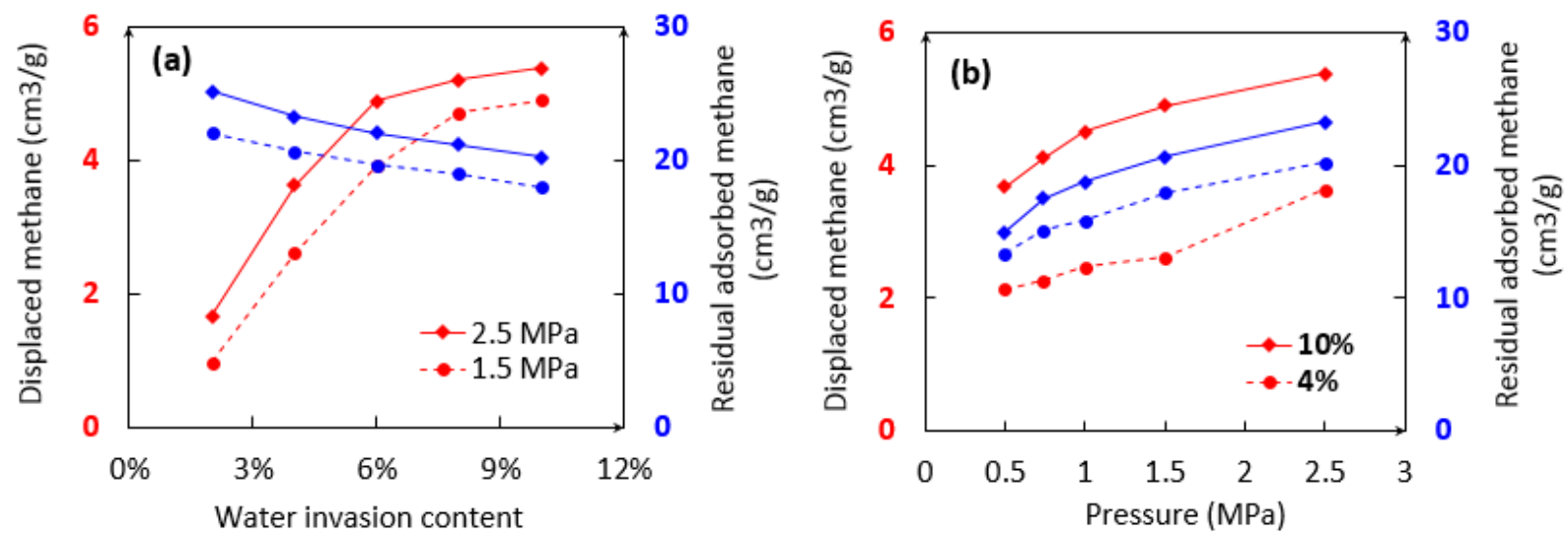

Figure 7 Relationship between displaced methane quantity and water invasion content and pressure

\subsection{Insights from the water-methane interaction}

As mentioned in the introduction, moisture influence on methane adsorption capacity has been extensively studied previously, however, these studies use moisture-equilibrium coal samples to conduct adsorption tests. This routinely adopted procedure is different 
from the water invasion process in engineering practice, where the adsorption equilibrium system of methane and dry coal is followed by the water invasion process. These previous works therefore do not allow researchers to study the interaction between adsorbed methane and the invasion water. The proposed experiments in this work overcome the historical shortcoming by changing the sequence of the dosing fluids, which allows us to gain new insights to understand how methane is displaced by the invading bulk water.

According to the experimental results in Figures 4-7, the following mechanisms are proposed to interpret how the bulk water interacts with both adsorbed methane and bulk methane in different scales of coal pores. For molded coal in a macroscopic level (intraparticle fissures), the water can displace free methane by volume displacement based on the law of mass balance, i.e., the same volume of water can displace the same volume of bulk methane. The invading water works like a piston to advance the free methane and the pressure of the whole system will not change, since the total free methane content does change. However, at a nanopore level $(<100 \mathrm{~nm}$ according to IUPAC classification, Thommes et al, 2015), the displacement scenario is different because of the interaction between invasion water and adsorbed/gaseous methane. There are two different mechanisms of the water and methane interaction: one is caused by the capillary effect and the other is caused by preferential flow in a coating mode because of the wetting and nanopore-rich nature of coal (Evan et al., 1973; Fang et al., 2017; Zhao et al., 2016). For the capillary effect in nanopores, the invading water displaces both the free methane and adsorbed methane and works like a piston since the pore is filled with water. The small fraction of the capillary water displaces the same volume of adsorbed methane and produces more free methane because of the high density feature of the adsorbed methane. This causes the pressure increase of the test cell. For the preferential flow, the invading water advances by coating the surface of the pore wall rather than by filling the whole pore bodies because of surface hydration of the pore surface (Feng et al., 2017; Zhao et al., 2016; Blake et al., 2004). This interpretation also agrees with the nanoscale observation through hyperpolarized 129 Xe and $1 \mathrm{H} \mathrm{PFG}$ NMR spectroscopy (Hu et al., 2018). They observed that water vapor adsorption can reduce the apparent pore sizes of nanopore from $6 \mathrm{~nm}$ and inhibit methane adsorption and diffusion in nanopores (Hu et al., 2018). Under this scenario, the water only displaces adsorbed methane without disturbing the free methane, and this will definitely cause a sharp pressure increase because of the increasing amount of free gas transformed from adsorbed methane. A schematic diagram of how water interacts with adsorbed and free methane in pore scale of molded coal is shown in Figure 8. 

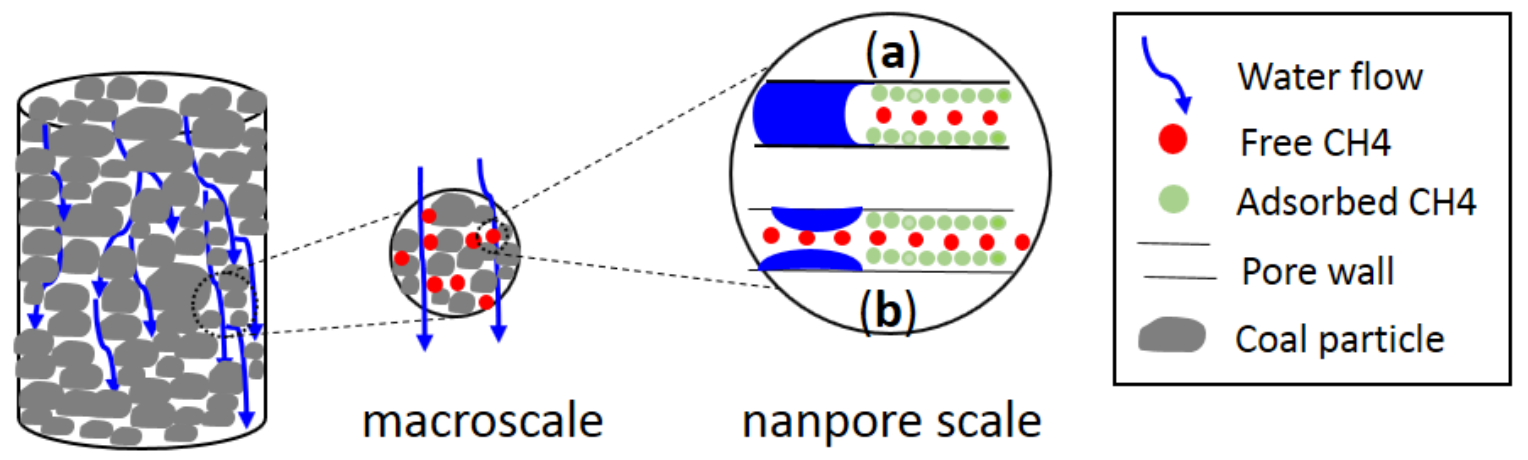

\section{Molded coal}

\section{Figure 8 Schematic diagram for methane-water interaction in molded coal at nanopore scale}

It is observed that the displaced methane rapidly increases under low water invasion content $(2 \%, 4 \%$ and $6 \%)$ and then almost reaches a maximum when the water uptake approximates $10 \%$ as shown in Figure $7 \mathrm{a}$. The similar phenomena were previously reported that sorption capacity decreases with increasing moisture content until the equilibrium moisture content is reached, and the gas sorption capacity remains constant above the equilibrium moisture content (Day et al., 2008; Joubert et al., 1973, 1974; Guo et al., 2015; Wang et al., 2014). For bulk water invasion, this behavior could be attributed to the different displacement mechanism under different water uptakes. Under low water uptake condition (around $2 \%, 4 \%$ and $6 \%$ ), the invading water advances by coating the pore surface in preferential flow pattern without filling the whole pore space, and the coating water film fully transforms adsorbed methane to free methane. As the water uptake increases (around 6\% and $8 \%$ in the work), capillary phenomena become more pronounced along with the preferential flow, and the capillary water transforms adsorbed methane to free methane. The displacement efficiency slightly decreases, because only a small fraction of the capillary water displaces adsorbed methane, and the majority of capillary water simultaneously advances free methane. As the water uptake reaches certain point (around 10\% in the work), most of the pore surfaces are coated by a water film while the capillary effect and the rest of the invading water mainly works as a piston to advance the free methane in coal, and most of the methane are mainly free gas. At the same time, most of the micropores $(<2 \mathrm{~nm})$ will also be filled by water under high invasion conditions. At this stage, the invading water does not enhance the free gas content and the pressure of the testing chamber does not change. Therefore, as the water uptake increases in coal, the displacement methane first increases rapidly, slows down, and finally keep constant as indicated in Figure 7a.

It is also shown that the displaced methane increases positively with increasing pressure as shown in Figure $7 \mathrm{~b}$. This is caused by the pressure dependent behavior of methane adsorption uptake in coal. Methane is adsorbed on coal surface by the Van der waals forces, and the adsorption uptake typically increases monotonically with increasing pressure following a Langmuir-style adsorption model (Tang et al., 2016). It is known that Van der waals forces are functions of distance away from the pore surface, and molecular 
simulation studies have demonstrated that the average volume (or thickness) of the adsorbed layer could be treated as a constant, and the density of adsorbed methane changes with pressure (Tian et al., 2017; Jin et al., 2017; Zhu et al., 2014; Zhang et al., 2014; Wu et al., 2016). As the pressure increases, the density of the adsorbed methane on the surface of pore wall increases, i.e., the adsorbed methane is more condensed with increasing pressure. A recent study of supercritical methane adsorption in coal also shows that the density of the adsorbed methane is a function of both pressure and temperature following a Langmuir-style equation (Wang et al., 2018), and this also coincidentally agrees with the finding from a molecular simulation study of methane in coal (Zhang et al., 2014). When invading water interacts with adsorbed methane in pores of different sizes, the displaced same volume of adsorbed methane under high pressure conditions will produce more free methane than that at low pressure conditions. This explains why displaced methane increases positively with increasing pressure as shown in Figure $7 \mathrm{~b}$. Furthermore, our results also demonstrate that the concept of "volumetric displacement of $\mathrm{CO} 2$ and $\mathrm{CH} 4$ by water" proposed by Day and Levy (Day et al., 2008; Levy et al., 1997) is inappropriate because the essential assumption that the density of the adsorbed phase is constant and independent of temperature and pressure is not valid.

\section{Engineering implication}

Our experimental work evidences that the invasion water has the capacity to displace both adsorbed methane and bulk methane in molded coal. The test procedure also simulates the real scenario of coal seam stimulation techniques using water-invasion based technologies. The obtained results provide new sights for understanding water and methane interaction in coals, which can be used to optimize the borehole arrangement design for draining coal seam gas through water invasion. For dry and low-permeability coal seams in underground coal mines, water invasion based techniques could be a promising techniques.

In China, water invasion techniques have been historically and widely used for coal and outburst prevention to ensure safe mining activities in underground coal mines (Kang et al., 1995). However, the adsorbed phase displacement effect by the invasion water is historically ignored (Xiao et al., 2009; Jiang et al., 2015). For example, it was routinely considered that the large amount of the bulk water displaces the bulk methane instead of adsorbed methane. High pressure water is also used to fracture coal seams to increase the permeability without seriously considering the water displacement effect. It is known that with increasing mining depth, the unique feature of deep coal seam, such as the high in situ stress, high in situ temperature, high seepage pressure, and strong mining disturbance, makes it challenging to drain deep coal seams using conventional techniques such as single borehole drainage method. The water invasion based technique becomes one of the suitable candidates because the invasion water has the capacity to enhance free methane content by transforming adsorbed methane to free methane in coals. However, this approach has to be treated with caution when borehole drainage method combined with water invasion is applied in engineering application because of the heterogeneous characteristics of coal seams. The heterogeneous properties of coal seams could result in the permeability variation at same coal seams. In a high permeability region, the displaced methane could flow out through coal seam fractures and the methane content therefore decreases. This means the injected water is 
helpful for decreasing methane content, and no additional drainage borehole is needed. However, the scenario is totally different for coal seams of low permeability. In low permeability coal seams, the displaced methane cannot flow out and will accumulate and form a high gas pressure zone around the water injection region. The injected water actually increases bulk methane content in this local region. The increased methane content could lead to methane induced disasters such as coal and gas outburst and interrupt the normal mining activities because of abnormal high methane content. In order to solve this problem, additional drainage boreholes are required for methane drainage to prevent the accumulation of bulk methane around the water injection region. A schematic diagram for drainage borehole design and arrangement in coal seams of low and high permeability is shown in Figure 9. Therefore, borehole drainage method combined with water injection have to be carefully designed according to the coal seam in situ conditions in order to efficiently drainage coal seam gas in underground mines.

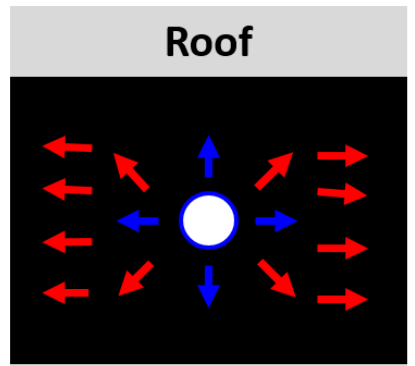

Floor

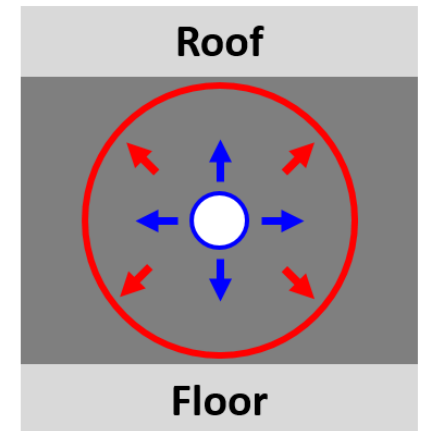

(b)

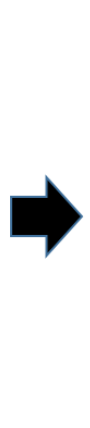

$\begin{array}{ll} & \text { Low permeability coal seam } \\ 0 & \text { High pressure zone } \\ \text { Gotential high pressure zone } & \text { Gas drainage borehole }\end{array}$

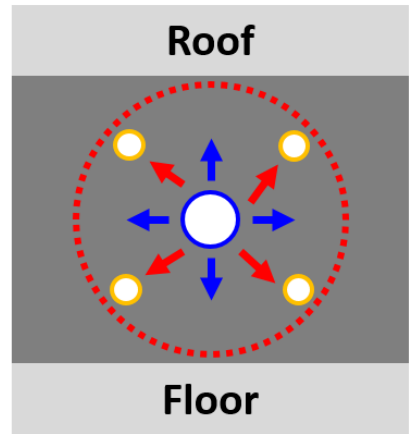

(c)

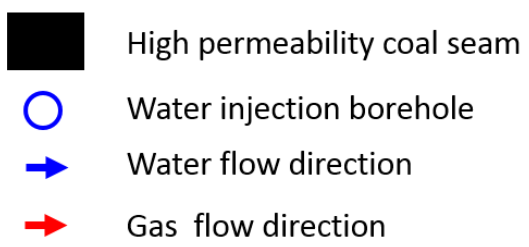

\section{Figure 9 Schematic diagram for drainage borehole design in coal seams of low and high permeability}

\section{Conclusions}

In order to understand the interaction between invasion bulk water and methane in coals, a home-made instrument is designed to simulate the water invasion process in coal seams. This novel design overcomes the shortcoming of the routinely used experimental methodology which uses moist coal to study the water influence on methane adsorption behavior in coal. Eighteen water invasion tests are conducted under different water invasion contents $(2,4,6,8,10 \%)$ and different initial equilibrium pressures $(0.5,0.74,1$, 1.5 and $2.5 \mathrm{MPa}$ ). This design allows the authors to study how the invasion water content and equilibrium pressure affect the interactions between bulk water and adsorbed/gaseous methane in coals. Some preliminary conclusions can be obtained from this work:

(1) When invasion bulk water interrupts the methane and coal equilibrium, it will displace adsorbed methane and transform adsorbed methane to free gaseous 
methane in nanopores of coal.

(2) Philip's model has the capacity to simulate the relationship between displacement methane content and time in earlier time of the test. The higher the water invasion content, the higher the calculated sorptivity, and there are no consistent relationships between initial equilibrium pressure and sorptivity. The reason is that the sorptivity is a measure of the medium capacity to absorb/desorb liquids by capillarity which is not affected by low pressures $(<2.5 \mathrm{MPa}$ in this work).

(3) The displaced methane quantity rapidly increases under low water invasion content $(2 \%, 4 \%$ and $6 \%$ in this work) and then almost reaches a maximum when the water uptake approximates $10 \%$. The displaced methane quantity increases with initial equilibrium pressure; the higher initial equilibrium pressure, the higher the displaced methane quantity. This observation can be attributed to the pressuredependent characteristics of adsorbed methane density.

(4) Experimental observations of methane and bulk water interaction in coal are reasonably explained at different scales by considering capillary effects and the preferential flow effect. At a macroscopic level (intraparticle fissures), the invasion water pushes the gaseous methane like a piston. At a nanopore level $(<100 \mathrm{~nm})$, the invasion water interacts with gaseous/adsorbed methane through the capillary effect and the preferential flow in a coating mode. For the capillary effect, the capillary water transforms both adsorbed and gaseous like a piston. For the preferential flow, the water only displaces the adsorbed phase and transforms adsorbed methane to gaseous methane by coating the pore walls.

(5) The work suggests that the enhanced bulk gas content effect due to invasion water needs to be considered for methane drainage using borehole drainage method combined with water injection in underground coal mines. For deep coal seams of low permeability, additional gas drainage boreholes around water injection boreholes are needed to flow out the accumulated bulk methane to prevent forming a high gas pressure zone.

\section{Acknowledgements}

The authors want to express their appreciation for funding provided by both the National Natural Science Foundation of China (No. 51274090) and the State Key Laboratory Cultivation Base for Gas Geology and Gas Control (Henan Polytechnic University) (No. WS2012B01). The part of the project has also received funding from the European Union's Horizon 2020 research and innovation programme under the Marie SklodowskaCurie grant agreement No 793128 (Marie Skłodowska-Curie Individual Fellowship). The author would also like to thank the anonymous reviewers for their comments that helped improve the manuscript. The authors would also like to thank the anonymous reviewers for their comments that help improve the manuscript. 


\section{Reference}

1. Allardice, D. J., Clemow, L. M., Favas, G., Jackson, W. R., Marshall, M., \& Sakurovs, R. (2003). The characterisation of different forms of water in low rank coals and some hydrothermally dried products. Fuel, 82(6), 661-667.

2. Blake, T. D., \& De Coninck, J. (2004). The influence of pore wettability on the dynamics of imbibition and drainage. Colloids and Surfaces A: Physicochemical and Engineering Aspects, 250(1), 395-402.

3. Bahadur, J., Contescu, C. I., Rai, D. K., Gallego, N. C., \& Melnichenko, Y. B. (2017). Clustering of water molecules in ultramicroporous carbon: In-situ small-angle neutron scattering. Carbon, 111, 681-688.

4. Bennion, D. B., Thomas, F. B., Bietz, R. F., \& Bennion, D. W. (1996). Water and hydrocarbon phase trapping in porous media-diagnosis, prevention and treatment. Journal of Canadian Petroleum Technology, 35(10).

5. Bennion, D. B., Thomas, F. B., Bietz, R. F., \& Bennion, D. W. (1999). Remediation of water and hydrocarbon phase trapping problems in low permeability gas reservoirs. Journal of Canadian Petroleum Technology, 38(08).

6. Busch, A., Gensterblum, Y., \& Krooss, B. M. (2007). High-pressure sorption of nitrogen, carbon dioxide, and their mixtures on argonne premium coals. Energy \& fuels, 21(3), 1640-1645.

7. Busch, A., \& Gensterblum, Y. (2011). CBM and CO2-ECBM related sorption processes in coal: a review. International Journal of Coal Geology, 87(2), 49-71.

8. Colinet, J., Listak, J. M., Organiscak, J. A., Rider, J. P., \& Wolfe, A. L. (2010). Best practices for dust control in coal mining.

9. Coppens, 1936 Ann. Mines Belg., 37 (1936), p. 173

10. Chen, D., Pan, Z., Liu, J., \& Connell, L. D. (2012). Modeling and simulation of moisture effect on gas storage and transport in coal seams. Energy \& Fuels, 26(3), 1695-1706.

11. Chen, X., \& Cheng, Y. (2015). Influence of the injected water on gas outburst disasters in coal mine. Natural Hazards, 76(2), 1093-1109.

12. Charrière, D., \& Behra, P. (2010). Water sorption on coals. Journal of colloid and interface science, 344(2), 460-467.

13. Clarkson, C. R., \& Bustin, R. M. (2000). Binary gas adsorption/desorption isotherms: effect of moisture and coal composition upon carbon dioxide selectivity over methane. International Journal of Coal Geology, 42(4), 241-271.

14. Day, S., Sakurovs, R., \& Weir, S. (2008). Supercritical gas sorption on moist coals. International Journal of Coal Geology, 74(3-4), 203-214.

15. Dacey, J. R., Clunie, J. C., \& Thomas, D. G. (1958). The adsorption of water by saran charcoal. Transactions of the Faraday Society, 54, 250-256.

16. Evans, D. G. (1973). The brown-coal/water system: Part 4. Shrinkage on drying. Fuel, 52(3), 186-190.

17. Fang, C., \& Qiao, R. (2017). Surface hydration drives rapid water imbibition into strongly hydrophilic nanopores. Physical Chemistry Chemical Physics, 19(31), 20506-20512. 
18. Fei, Y., Marshall, M., Jackson, W. R., Chaffee, A. L., \& Allardice, D. J. (2006). A comparison of adsorption isotherms using different techniques for a range of raw, water-and acid-washed lignites. Fuel, 85(10-11), 1559-1565.

19. Fitzgerald, J. E., Pan, Z., Sudibandriyo, M., Robinson Jr, R. L., Gasem, K. A. M., \& Reeves, S. (2005). Adsorption of methane, nitrogen, carbon dioxide and their mixtures on wet Tiffany coal. Fuel, 84(18), 2351-2363.

20.Gale, J., \& Freund, P. (2001). Coal-bed methane enhancement with CO2 sequestration worldwide potential. Environmental Geosciences, 8(3), 210-217.

21. Godec, M., Koperna, G., \& Gale, J. (2014). CO2-ECBM: a review of its status and global potential. Energy Procedia, 63, 5858-5869.

22. GUO, H. Y., \& SU, X. B. (2010). Research on the mechanism of gas emission inhibition in water-flooding coal seam [J]. Journal of China Coal Society, 6, 928931.

23. Guo, H., Cheng, Y., Wang, L., Lu, S., \& Jin, K. (2015). Experimental study on the effect of moisture on low-rank coal adsorption characteristics. Journal of Natural Gas Science and Engineering, 24, 245-251.

24. He, M. C., Xie, H. P., Peng, S. P., \& Jiang, Y. D. (2005). Study on rock mechanics in deep mining engineering. Chinese Journal of Rock Mechanics and Engineering, 24(16), 2803-2813.

25. Hu, Y., Li, M., Hou, G., Xu, S., Gong, K., Liu, X., ... \& Bao, X. (2018). The role of water in methane adsorption and diffusion within nanoporous silica investigated by hyperpolarized 129 Xe and 1 H PFG NMR spectroscopy. Nano Research, 11(1), 360-369.

26. Huang, B., Liu, C., Fu, J., \& Guan, H. (2011). Hydraulic fracturing after water pressure control blasting for increased fracturing. International Journal of Rock Mechanics and Mining Sciences, 48(6), 976-983.

27. Hall, F. E., Chunhe, Z., Gasem, K. A. M., Robinson Jr, R. L., \& Dan, Y. (1994, January). Adsorption of pure methane, nitrogen, and carbon dioxide and their binary mixtures on wet Fruitland coal. In SPE Eastern Regional Meeting. Society of Petroleum Engineers.

28. Humphrey, M. D., Istok, J. D., Flint, L. E., \& Flint, A. L. (1996). Improved method for measuring water imbibition rates on low-permeability porous media. Soil Science Society of America Journal, 60(1), 28-34.

29. Hu, M. Q., Persoff, P., \& Wang, J. S. (2001). Laboratory measurement of water imbibition into low-permeability welded tuff. Journal of Hydrology, 242(1-2), 64-78.

30. Ibrahim, A. F., \& Nasr-El-Din, H. A. (2015). A comprehensive model to history match and predict gas/water production from coal seams. International Journal of Coal Geology, 146, 79-90.

31. Joubert, J. I., Grein, C. T., \& Bienstock, D. (1974). Effect of moisture on the methane capacity of American coals. Fuel, 53(3), 186-191.

32. Joubert, J. I., Grein, C. T., \& Bienstock, D. (1973). Sorption of methane in moist coal. Fuel, 52(3), 181-185.

33. J. Nishino. Adsorption of water vapor and carbon dioxide at carboxylic functional groups on the surface of coal. Fuel, 80 (5) (2001), pp. 757-764. 
34. J. Bahadur, C.I. Contescu, D.K. Rai, N.C. Gallego, Y.B. Melnichenko Clustering of water molecules in ultramicroporous carbon: in-situ small-angle neutron scattering. Carbon, 111 (2017), pp. 681-688

35. Jiang, J., Cheng, Y., Mou, J., Jin, K., \& Cui, J. (2015). Effect of water invasion on outburst predictive index of low rank coals in Dalong mine. PloS one, 10(7), e0132355.

36. Jin, Z. (2017). Effect of nano-confinement on high pressure methane flow characteristics. Journal of Natural Gas Science and Engineering, 45, 575-583.

37. Jin, Zhehui, and Abbas Firoozabadi. "Effect of water on methane and carbon dioxide sorption in clay minerals by Monte Carlo simulations." Fluid Phase Equilibria 382 (2014): 10-20.

38. Kang TH. Coal Seam Water Injection Infiltration Characteristics and Classification research. Chinese journal of rock mechanics and engineering. 1995; 14(3): 260 263.

39. Krooss, B. V., Van Bergen, F., Gensterblum, Y., Siemons, N., Pagnier, H. J. M., \& David, P. (2002). High-pressure methane and carbon dioxide adsorption on dry and moisture-equilibrated Pennsylvanian coals. International Journal of Coal Geology, 51(2), 69-92.

40. Lin, B., Zou, Q., Liang, Y., Xie, J., \& Yang, H. (2018). Response characteristics of coal subjected to coupling static and waterjet impact loads. International Journal of Rock Mechanics and Mining Sciences, 103, 155-167.

41. Levy, J. H., Day, S. J., \& Killingley, J. S. (1997). Methane capacities of Bowen Basin coals related to coal properties. Fuel, 76(9), 813-819.

42. Lynch, L. J., \& Webster, D. S. (1982). Effect of thermal treatment on the interaction of brown coal and water: a nuclear magnetic resonance study. Fuel, 61(3), 271275.

43. Liu, X. Q., He, X., Qiu, N. X., Yang, X., Tian, Z. Y., Li, M. J., \& Xue, Y. (2016). Molecular simulation of $\mathrm{CH} 4, \mathrm{CO} 2, \mathrm{H} 2 \mathrm{O}$ and $\mathrm{N} 2$ molecules adsorption on heterogeneous surface models of coal. Applied Surface Science, 389, 894-905.

44. Liu, J., Peach, C. J., \& Spiers, C. J. (2016). Anisotropic swelling behaviour of coal matrix cubes exposed to water vapour: Effects of relative humidity and sample size. International Journal of Coal Geology, 167, 119-135.

45. McCutcheon, A. L., Barton, W. A., \& Wilson, M. A. (2001). Kinetics of water adsorption/desorption on bituminous coals. Energy \& fuels, 15(6), 1387-1395.

46. McCutcheon, A. L., Barton, W. A., \& Wilson, M. A. (2003). Characterization of water adsorbed on bituminous coals. Energy \& fuels, 17(1), 107-112.

47. Moore, T. A., \& Crosdale, P. J. (2006, May). The effect of moisture and temperature on adsorption isotherms of a low-rank coal: Implications for reservoir modeling. In 2006 International Coalbed Methane Symposium, Tuscaloosa, Alabama (Vol. 645).

48. Mahajan, O. P., and P. L. Walker Jr. "Water adsorption on coals." Fuel 50.3 (1971): 308-317.

49. Nishino, J. (2001). Adsorption of water vapor and carbon dioxide at carboxylic functional groups on the surface of coal. Fuel, 80(5), 757-764. 
50. Philip, J. R. (1957). The theory of infiltration: 4. Sorptivity and algebraic infiltration equations. Soil science, 84(3), 257-264.

51.Pan, Z., Connell, L. D., Camilleri, M., \& Connelly, L. (2010). Effects of matrix moisture on gas diffusion and flow in coal. Fuel, 89(11), 3207-3217.

52. Rogers, R., Ramurthy, K., Rodvelt, G. \& Mullen, M. (2007). Coalbed methane: Principles and practice (3rd). Oktibbeha Publishing Co. LLC.

53. Seemann, T., Bertier, P., Krooss, B. M., \& Stanjek, H. (2017). Water vapour sorption on mudrocks. Geological Society, London, Special Publications, 454(1), 201-233.

54. Seidle, J. (2011). Fundamentals of coalbed methane reservoir engineering. PennWell Books.

55. Salmachi, A., \& Haghighi, M. (2012). Feasibility study of thermally enhanced gas recovery of coal seam gas reservoirs using geothermal resources. Energy \& Fuels, 26(8), 5048-5059.

56. Suuberg, E. M., Otake, Y., Yun, Y., \& Deevi, S. C. (1993). Role of moisture in coal structure and the effects of drying upon the accessibility of coal structure. Energy \& Fuels, 7(3), 384-392.

57.Švábová, M., Weishauptová, Z., \& Přibyl, O. (2011). Water vapour adsorption on coal. Fuel, 90(5), 1892-1899.

58. Tang, X., Ripepi, N., Valentine, K. A., Keles, C., Long, T., \& Gonciaruk, A. (2017). Water vapor sorption on Marcellus shale: measurement, modeling and thermodynamic analysis. Fuel, 209, 606-614.

59. Tang, X., Ripepi, N., Luxbacher, K., \& Pitcher, E. (2017). Adsorption Models for Methane in Shales: Review, Comparison, and Application. Energy \& Fuels, 31(10), 10787-10801.

60.Teng, T., Wang, J. G., Gao, F., Ju, Y., \& Xia, T. (2016). Impact of water film evaporation on gas transport property in fractured wet coal seams. Transport in Porous Media, 113(2), 357-382.

61.Tang, X., Ripepi, N., \& Gilliland, E. (2016). Isothermal adsorption kinetics properties of carbon dioxide in crushed coal. Greenhouse Gases: Science and Technology, 6(2), 260-274.

62. Thommes, M., Kaneko, K., Neimark, A. V., Olivier, J. P., Rodriguez-Reinoso, F., Rouquerol, J., \& Sing, K. S. (2015). Physisorption of gases, with special reference to the evaluation of surface area and pore size distribution (IUPAC Technical Report). Pure and Applied Chemistry, 87(9-10), 1051-1069.

63. Tang, X. Ripepi, N. (2016). Temperature-dependent Langmuir model in the coal and methane sorption process: Statistical relationship, Transactions of the Society for Mining, Metallurgy \& Exploration, 340, 61-69.

64. Tian, Y., Yan, C., \& Jin, Z. (2017). Characterization of Methane Excess and Absolute Adsorption in Various Clay Nanopores from Molecular Simulation. Scientific reports, 7(1), 12040.

65. Unsworth, J. F., Fowler, C. S., \& Jones, L. F. (1989). Moisture in coal: 2. Maceral effects on pore structure. Fuel, 68(1), 18-26. 
66. Van Bergen, F., Spiers, C., Floor, G., \& Bots, P. (2009). Strain development in unconfined coals exposed to $\mathrm{CO} 2, \mathrm{CH} 4$ and $\mathrm{Ar}$ : effect of moisture. International Journal of Coal Geology, 77(1-2), 43-53.

67. Wang, Z., Tang, X., Yue, G., Kang, B., Xie, C., \& Li, X. (2015). Physical simulation of temperature influence on methane sorption and kinetics in coal: Benefits of temperature under $273.15 \mathrm{~K}$. Fuel, 158, 207-216.

68. Wu, K., Chen, Z., Li, X., \& Dong, X. (2016). Methane storage in nanoporous material at supercritical temperature over a wide range of pressures. Scientific reports, 6, 33461.

69. Wang, Z., \& Tang, X. (2018). New insights from supercritical methane adsorption in coal: gas resource estimation, thermodynamics and engineering application. Energy \& Fuels. DOI: 10.1021/acs.energyfuels.8b00477.

70. Wiig, E. O., \& Juhola, A. J. (1949). The adsorption of water vapor on activated charcoal. Journal of the American Chemical Society, 71(2), 561-568.

71. Wan, K., He, Q., Miao, Z., Liu, X., \& Huang, S. (2016). Water desorption isotherms and net isosteric heat of desorption on lignite. Fuel, 171, 101-107.

72. Wang, L., \& Jiang, B. (2016). Experimental study of the effect of static water on imbibition gas recovery in coalbed methane reservoirs. Journal of Natural Gas Science and Engineering, 35, 1284-1292.

73. Wang, Z. Su, W., Chen, X. \& Wu, J. (2015) Experimental study and mechanism analysis on natural water absorption and imbibition test of gas-bearing coal. Coal Science and Technology, 43(8), 72-76.

74. Wang, K., Zang, J., Feng, Y., \& Wu, Y. (2014). Effects of moisture on diffusion kinetics in Chinese coals during methane desorption. Journal of Natural Gas Science and Engineering, 21, 1005-1014.

75. White, C. M., Smith, D. H., Jones, K. L., Goodman, A. L., Jikich, S. A., LaCount, R. B., ... \& Schroeder, K. T. (2005). Sequestration of carbon dioxide in coal with enhanced coalbed methane recovery a review. Energy \& Fuels, 19(3), 659-724.

76. Wu, J., Yu, J., Wang, Z., Fu, X., \& Su, W. (2018). Experimental investigation on spontaneous imbibition of water in coal: Implications for methane desorption and diffusion. Fuel, 231, 427-437.

77. Xiao, Z., \& Wang, Z. (2009). Status and progress of studies on mechanism of preventing coal and gas outburst by coal seam infusion. China Safety Science Journal, 19(10), 150-157.

78. Yu, L., Xue, J. H., LIU, Q. S. \& Liu, B.(2011). Surrounding rock stability control theory and support technique in deep rock roadway for coal mine. Journal of China Coal Society, 36(4), 535-543.

79. Yu, J., Tahmasebi, A., Han, Y., Yin, F., \& Li, X. (2013). A review on water in low rank coals: the existence, interaction with coal structure and effects on coal utilization. Fuel Processing Technology, 106, 9-20.

80.Zhang, T., Ellis, G. S., Ruppel, S. C., Milliken, K., \& Yang, R. (2012). Effect of organic-matter type and thermal maturity on methane adsorption in shale-gas systems. Organic geochemistry, 47, 120-131. 
81.Zhao, B., MacMinn, C. W., \& Juanes, R. (2016). Wettability control on multiphase flow in patterned microfluidics. Proceedings of the National Academy of Sciences, 113(37), 10251-10256.

82.Zhu, X., \& Zhao, Y. P. (2014). Atomic mechanisms and equation of state of methane adsorption in carbon nanopores. The Journal of Physical Chemistry C, 118(31), 17737-17744.

83.Zhou, Y., Sun, W., Chu, W., Liu, X., Jing, F., \& Xue, Y. (2016). Theoretical insight into the enhanced $\mathrm{CH} 4$ desorption via $\mathrm{H} 2 \mathrm{O}$ adsorption on different rank coal surfaces. Journal of Energy Chemistry, 25(4), 677-682.

84.Zhang, J., Clennell, M. B., Dewhurst, D. N., \& Liu, K. (2014). Combined Monte Carlo and molecular dynamics simulation of methane adsorption on dry and moist coal. Fuel, 122, 186-197. 